\title{
Workers' Migration and Remittances in Bangladesh
}

Khawaja A. Mamun

Sacred Heart University • Fairfield, CT

Hiranya K. Nath

Sam Houston State University • Huntsville, TX

\section{Abstract}

Bangladesh has sent more than 6.7 million workers to over 140 countries during a period of more than three decades since the mid-1970s. Most of these workers temporarily migrated to work in Middle East and Southeast Asia. This mass movement of temporary migrant workers has, to some extent, eased unemployment pressures on the over-burdened labor market in this highly populated country. More importantly, the remittance transfers received from these migrant workers have reached a phenomenal level of over 10 billion US dollars in 2009, approximately 12 percent of GDP in Bangladesh. This paper analyzes the trends and various other aspects of workers' migration and remittances in Bangladesh. It further discusses the micro and macroeconomic impacts of remittances. While most remittance transfers have been used by migrant-sending households for consumption, there is evidence to show that these transfers have helped reduce poverty in Bangladesh. The analysis presented in this paper further indicates that these remittances may have significant effects on other macroeconomic variables as well.

\section{Introduction}

A labor-abundant country, Bangladesh has sent over an estimated 6.7 million migrant workers to more that 140 countries across the globe over a period of more than three decades since the mid-1970s. ${ }^{1}$ The countries of Middle East and Northern Africa have been the major destinations for these migrant workers. In the recent past, there have been large flows of Bangladeshi migrant workers to Southeast Asia - particularly to Malaysia and Singapore - as well. The natural resource based economic prosperity of the first group of destination countries since the 1970s has created a large demand mainly for unskilled and semi-skilled workers to work in different sectors of those economies. Similarly, the economic boom of the Southeast Asian countries in the late 1980s and the 1990s generated demand for unskilled and semi-skilled workers. Bangladesh with a large population and limited economic opportunities has decidedly taken advantage of economic growth and prosperity in those countries.

These flows of migrants leaving the country have not only fulfilled the mandate of the government policy to encourage out-migration as a means of eas- 
ing unemployment pressure on Bangladesh' ever exploding labor market, but also the remittances received from the migrant workers have had significant impact on the economy. With more than 10 billion U.S. dollars (USD) in remittances during 2009 alone, Bangladesh has been among the major remittance-receiving countries in the world and it has maintained this status for last several years. ${ }^{2}$ This amount is about 12 percent of GDP and more than half of total export earnings. It may be noted that if the money remitted through informal channels are taken into account, the magnitude will be much larger. ${ }^{3}$ Furthermore, not surprisingly, the countries of Middle East have been the major sources of these remittance transfers. As noted by an official associated with labor migration, "remittances have been causing a silent economic revolution in Bangladesh."4 However, the broader impacts of remittances in the economy have not been fully assessed. There have been only a few studies that use micro-level survey data to examine the economic effects of remittances in Bangladesh. To the best of our knowledge, there is hardly any work that systematically investigate the overall macroeconomic impact of remittances in Bangladesh. ${ }^{5}$ However, studies for other countries have shown that these remittance flows could have significant macroeconomic consequences. ${ }^{6}$

This paper is intended to examine the dual phenomena of workers' migration and remittances in Bangladesh. Over the years, under the government patronage, the international migration of workers has taken some pressure off from the domestic labor market and has purportedly enhanced the economic well-being of the families left behind by the migrants. However, given the size of the remittance inflows - primarily from these migrant workers - relative to the total income generated in the domestic economy, there could be significant impacts of these inflows on the overall economy. Intuitively, there are several ways in which these inflows may have macroeconomic impact in a poor country like Bangladesh. For example, if a significant part of the remittances is used for saving and investment, it could lead to higher growth of the economy in the long-run. If the remittance-receiving families spend a significant amount of these transfers on education and health - two important elements of human capital - this may also contribute to long-run growth of the economy. Furthermore, by alleviating foreign exchange constraint, remittances may facilitate imports of capital goods and other important raw materials that are used in the production processes. Even in the short-run, remittances may contribute to the growth of output in the economy by augmenting aggregate demand if the remittance-receiving households spend most of these transfers on consumption.

The rest of the paper is organized as follows. In section 2, we discuss various trends of international migration of workers from Bangladesh. Different aspects 
of remittance transfers over last three decades are discussed in section 3. Section 4 discusses the impacts of remittances in Bangladesh. The discussion is divided into two subsection. In the first subsection, we report and discuss the findings of the previous micro-level studies. In the second subsection, we present the preliminary results from a vector autoregressive (VAR) macro model to shed lights on the macroeconomic impacts of remittances in Bangladesh. The next section includes our concluding remarks and a brief outline of future research.

\section{International Migration from Bangladesh}

There are two major patterns in international migration from Bangladesh: one to the industrialized west that includes the United Kingdom and the United States, and the other to Middle East and Southeast Asia. The migration to the industrialized countries is perceived to be long term or permanent in nature while migration to Middle East and Southeast Asia is usually for short term. The Bangladeshi immigrants living in the industrialized countries of Europe and North America can be divided into two distinct groups: a group of well-educated, high or middle income people of Bangladeshi origin, and the other belonging to the low income or unemployed segments of the population. The origins of migration to these countries can be traced back to the British colonial period. Most of these early migrants were employed as low-skilled workers and there has been hardly any upward economic mobility. However, a very small number of Bangladeshis during the colonial period moved to the U.K. to pursue higher studies. In recent years, larger number of students and professionals migrated to the U.K. and the U.S. and chose to live there permanently. The government does not have any systematic record of the extent and composition of this long-term migration. However, according to an unofficial estimate, over a million Bangladeshi immigrants live in the industrialized countries of the west (Siddiqui, 2004).

International migration to the countries of Middle East, North Africa, and Southeast Asia took place mainly after the independence of Bangladesh in 1971. The rise in oil prices in the 1970s increased the demand for low-skilled workers to work in the infrastructure development projects in the Middle Eastern countries. Later, there were similar demands from the newly industrialized countries of the Southeast Asia. Migration to these regions has been characterized by short-term employment with specific job contracts and migrants returning home after completion of the contract period.

The Bureau of Manpower, Employment and Training (BMET) maintains a database on the short term labor migrants who officially go overseas for employ- 
ment. According to the official statistics, between 1976 and 2009, the total number of Bangladeshis working abroad as short-term migrants stands at about 6.7 million. Figure 1 presents the total number of migrant workers for each year between 1976 and 2009. The major destination countries for these short-term migrant workers include Saudi Arabia (KSA), the United Arab Emirates (UAE), Malaysia, Kuwait, Oman, Singapore, Bahrain, Qatar, and Libya (see Figure 2). Saudi Arabia alone hosts about 40 percent of the total short-term migrant workers from Bangladesh.

Figure 1

Total Number of International Migrant Workers from Bangladesh: 1976-2009

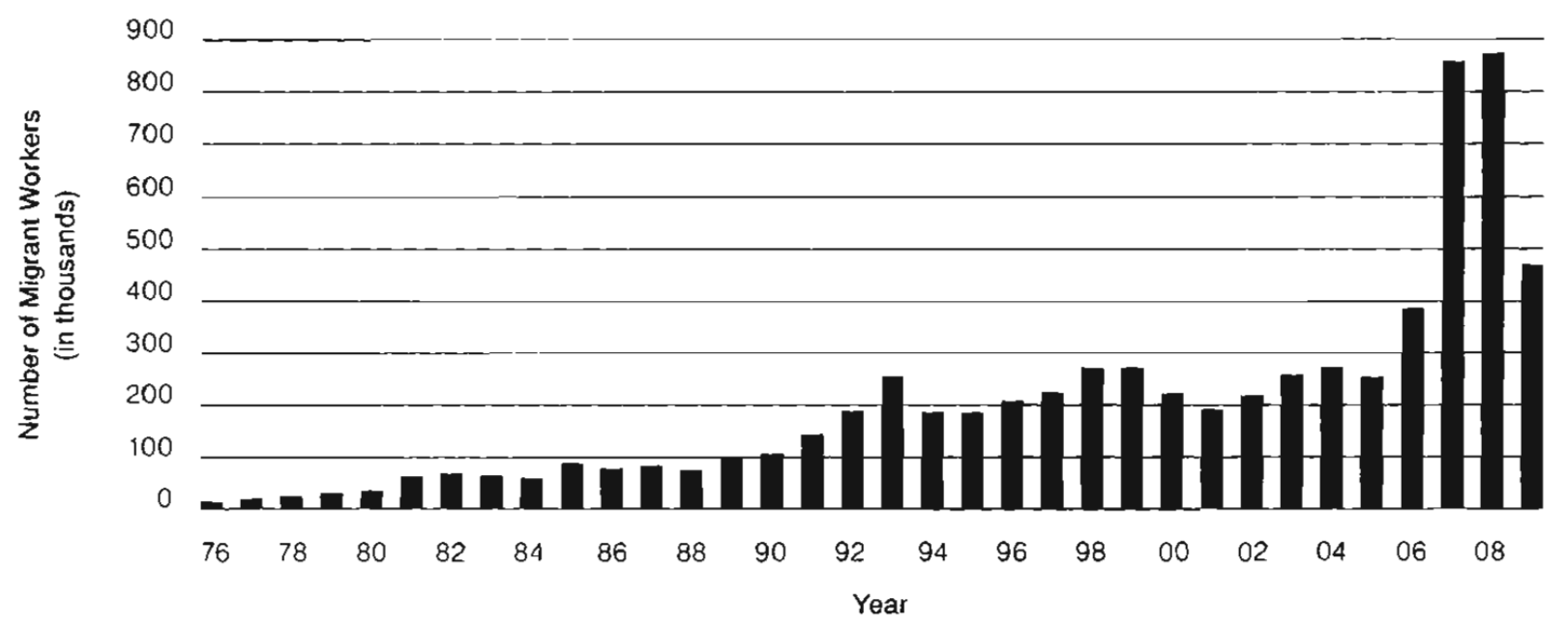

Figure 2

International Migrant Workers from Bangladesh by Country of Destination (in Percentages): 1976-2009

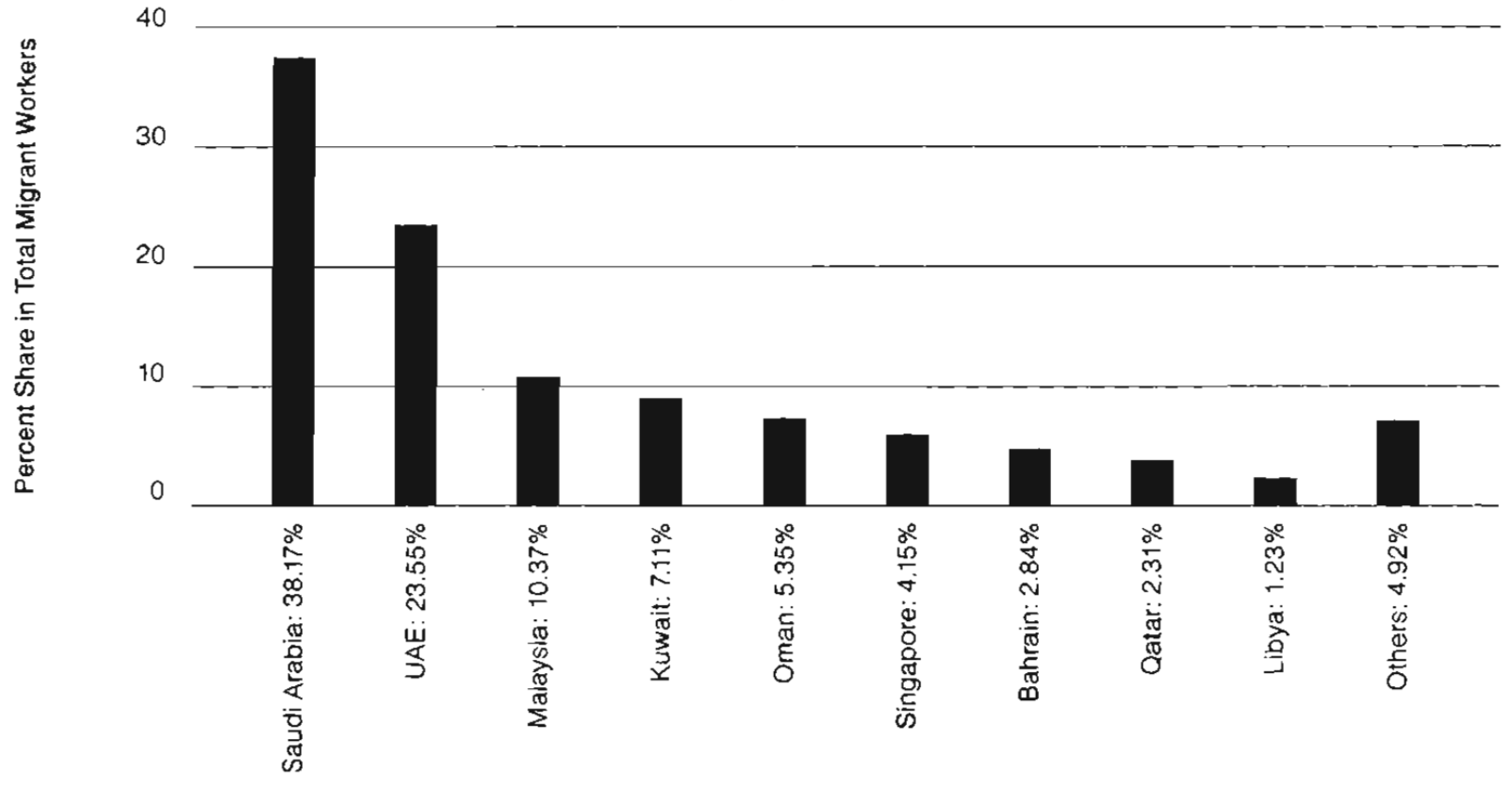


Table 1

Number of Migrant Workers from Bangladesh by Country of Destination: 1976 - 2009

\begin{tabular}{|c|c|c|c|c|c|c|c|c|c|c|c|c|c|c|c|c|c|c|c|c|c|c|c|}
\hline \multicolumn{24}{|c|}{ Country } \\
\hline Year & KSA & VAE & Kuwait & Oman & Qatar & Bahrain & Lebanon & Jordan & Libya & Sudan & Malaysia & Sing. 5 & S. Korea & UK & Italy & Japan & Egypt & Brunei & Maurit. & Romania & Others & $\begin{array}{l}\text { Misc. } \\
\text { Clear. }\end{array}$ & $\begin{array}{c}\text { Total } \\
\text { Empl'mt. }\end{array}$ \\
\hline 1976 & 217 & 1,989 & 643 & 113 & 1,221 & 335 & & & 173 & & & & & & & & & & & & 1,396 & & 6,087 \\
\hline 1977 & 1,379 & 5,819 & 1,315 & 1,492 & 2,262 & 870 & & & 718 & & & & & & & & & & & & 1,870 & & 15,725 \\
\hline 1978 & 3,212 & 7,512 & 2,243 & 2,877 & 1,303 & 762 & & & 2,394 & & 23 & & & & & & & & & & 2.483 & & 22,809 \\
\hline 1979 & 6.476 & 5,069 & 2,298 & 3,777 & 1,383 & 827 & & & 1,969 & & & 110 & & & & & & & & & 2,586 & & 24,495 \\
\hline 1980 & 8,695 & 4,847 & 3.687 & 4,745 & 1.455 & 1,351 & & & 2,976 & & 3 & 385 & & & & & & & & & 1,929 & & 30,073 \\
\hline 1981 & 13,384 & 6,418 & 5,464 & 7,352 & 2,268 & 1,392 & & & 4,162 & & & 1,083 & & & & & & & & & 14,264 & & 55,787 \\
\hline 1982 & 16,294 & 6.863 & 7,244 & 8,248 & 6,252 & 2,037 & & & 2,071 & & & 331 & & & & & & & & & 13,422 & & 62.762 \\
\hline 1983 & 12,928 & 6,615 & 10,283 & 11,110 & 7,556 & 2,473 & & & 2,209 & & 23 & 178 & & & & & & & & & 5,845 & & 59,220 \\
\hline 1984 & 20,399 & 5,185 & 5,627 & 10,448 & 2,726 & 2,300 & & & 3,386 & & & 718 & & & & & & & & & 5,925 & & 56,714 \\
\hline 1985 & 37,133 & 8.336 & 7,384 & 9,218 & 4,751 & 2,965 & & & 1,514 & & & 792 & & & & & & & & & 5,601 & & 77.694 \\
\hline 1986 & 27.235 & 8,790 & 10,286 & 6,255 & 4,847 & 2,597 & & & 3,111 & & 530 & 25 & & & & & & & & & 4,982 & & 68,658 \\
\hline 1987 & 39,292 & 9,953 & 9,559 & 440 & 5,889 & 2,055 & & & 2,271 & & & & & & & & & & & & 4,558 & & 74,017 \\
\hline 1988 & 27,622 & 13,437 & 6,524 & 2,219 & 7,390 & 3,268 & & & 2,759 & & 2 & & & & & & & & & & 4,900 & & 68,121 \\
\hline 1989 & 39,949 & 15.184 & 12.404 & 15.429 & 8.462 & 4.830 & & & 1,609 & & 401 & 229 & & & & & & & & & 3.227 & & 101,724 \\
\hline 1990 & 57,486 & 8,307 & 5,957 & 13,980 & 7,672 & $4,56.3$ & & & 471 & & 1,385 & 776 & & & & & & & & & 3,217 & & 103,814 \\
\hline 1991 & 75,656 & 8,583 & 28,574 & 23,087 & 3,772 & 3,480 & & & 1,124 & & 1.628 & 642 & & & & & & & & & 585 & & $147,\{31$ \\
\hline 1992 & 93,132 & 12,975 & 34,377 & 25,825 & 3,251 & 5,804 & 37 & & 1,617 & & 10,537 & 313 & & & & & & 228 & 12 & & 16 & & 188,124 \\
\hline 1993 & 106.387 & 15,810 & 26,407 & 15,866 & 2,441 & 5,396 & 37 & & 1,800 & & 67,938 & 1,739 & & & & & & 328 & 12 & & 347 & & 244,508 \\
\hline 1994 & 91,385 & 15,051 & 14,912 & 6,470 & 624 & 4,233 & 382 & & 1,864 & & 47,826 & 391 & 1,558 & & & & & 1,335 & 26 & & 269 & & 186,326 \\
\hline 1995 & 84,009 & 14,686 & 17,492 & 20,949 & 71 & 3,004 & 406 & & 1,106 & & 35,174 & 3,762 & 3,315 & & & & & 2.659 & 229 & & 681 & & 187.543 \\
\hline 1996 & 72,734 & 23,812 & 21,042 & 8,691 & 112 & 3.759 & 490 & & 1,966 & & 66,631 & 5.304 & 2,759 & & & & & 3,062 & 196 & & 1,156 & & 211,714 \\
\hline 1997 & 106.534 & 54,719 & 21,126 & 5,985 & 1,873 & 5,010 & 907 & & 1.934 & & 2,844 & 27.401 & 889 & & & & & 303 & 238 & & 1,374 & & 231,077 \\
\hline 1998 & 158,715 & 38,796 & 25,444 & 4,779 & 6,806 & 7,014 & 1,389 & & 1,254 & 8 & 551 & 21,728 & 578 & & & & & 169 & 16 & & 420 & & 267,667 \\
\hline 1999 & 185,739 & 32,344 & 22,400 & 4,045 & 5,611 & 4,639 & 219 & & 1,744 & 16 & & 9,596 & 1,501 & & & 7 & & 1 & 139 & & 181 & & 268,182 \\
\hline 2000 & 144,618 & 34,034 & 594 & 5,258 & 1,433 & 4,637 & & & 1,010 & 54 & 17,237 & 11,095 & 990 & & & 22 & 9 & 1.420 & 271 & & 4 & & 222,686 \\
\hline 2001 & 137,248 & 16.252 & 5,341 & 4,561 & 223 & 4,371 & & & 450 & 153 & 4.921 & 9.615 & 1,561 & & & 19 & 3 & 2,958 & 272 & & 1,017 & & 188,965 \\
\hline 2002 & 163,269 & 25,462 & 15.769 & 3.854 & 552 & 5.421 & 2 & 1,829 & 1,574 & 136 & 85 & 6.856 & 28 & & 19 & 37 & $\lceil 7$ & 154 & 59 & & 133 & & 225.256 \\
\hline 2003 & 162,131 & 37,346 & 26,722 & 4,029 & 94 & 7,482 & 3 & 2,128 & 2,855 & 784 & 28 & 5,304 & 3,771 & 166 & 28 & 12 & 26 & 980 & & & 301 & & 254,190 \\
\hline 2004 & 139,031 & 47,012 & 41,108 & 4,435 & 1.268 & 9,194 & & 6,022 & 606 & 923 & 224 & 6,948 & 215 & 2,055 & 550 & 47 & 33 & 1,802 & 44 & & 2.859 & 8.582 & 272,958 \\
\hline 2005 & 80,425 & 61,978 & 47,029 & 4,827 & 2,114 & 10,716 & 14 & 9,101 & 972 & 885 & 2.911 & 9,651 & 223 & 2,793 & 950 & 79 & 207 & 191 & 1,381 & & 4,015 & 12,240 & 252,702 \\
\hline 2006 & 109,513 & 130,204 & 35,775 & 8,082 & 7,691 & 16,355 & 821 & 2,822 & 104 & 2,380 & 20,469 & 20,139 & 992 & 1,625 & 1,428 & 174 & 639 & 496 & 2,090 & & 8,995 & 10,722 & 381,516 \\
\hline 2007 & 204,112 & 226,392 & 4,212 & 17.478 & 15,130 & 16,433 & 3,541 & 494 & 1,480 & 1.726 & 273,201 & 38,324 & 39 & 972 & 10,950 & 164 & 1,068 & 1,186 & 3,658 & & 1,827 & 10,222 & 832,609 \\
\hline 2008 & 132,124 & 419.355 & 319 & 52.896 & 25.548 & 13.182 & 8,444 & 682 & 5,067 & 170 & 131,762 & 56,581 & 1,521 & 957 & 6,978 & 133 & 1,891 & 1.054 & 3.071 & 830 & 1,631 & 10.914 & 875,055 \\
\hline 2009 & 14,666 & 258,348 & 10 & 41,704 & 11,672 & 28,426 & 13,941 & 1,691 & 22,742 & 514 & 12,402 & 39,581 & 1,474 & 1,253 & 5,339 & 39 & 3,018 & 2,699 & 1.826 & 229 & 5,219 & 8,485 & 475,278 \\
\hline Total & $2,573,129$ & $1,587,483$ & 479,571 & 360,524 & 155,723 & 191,181 & 30,633 & 24,769 & 83.062 & 7,749 & 698,736 & 279,597 & 21,414 & 9,816 & 26,192 & 733 & 6,911 & 21,025 & 13,540 & 1,059 & 107,175 & 61.165 & $6,741,187$ \\
\hline$\%$ & 38.17 & 23.55 & 7.11 & 5.35 & 2.31 & 2.84 & 0.45 & 0.37 & 1.23 & 0.11 & 10.37 & 4.15 & 0.32 & 0.15 & 0.39 & 0.01 & 0.10 & 0.31 & 0.20 & 0.02 & 1.59 & 0.91 & \\
\hline
\end{tabular}


As it is clear from Figure 1 and Table 1 , there have been year-to-year variations in total and country-wise composition of international migration from Bangladesh. For example, there was a drop in migration to Middle East during the gulf war in the early 1990s. After the war was over, there was a greater demand for migrant workers to work in the post-war reconstruction efforts. Similarly, there was a decrease in demand for Bangladeshi workers in the Southeast Asian countries immediately after the financial crisis of 1997 . As recently as 2006 through 2008 , there was a substantial increase in demand for migrant workers in the UAE, presumably triggered by the economic boom caused mainly by manifold increases in oil revenue. During 2007, the demand for Bangladeshi workers increased significantly in Malayasia as well. The significant drop in the number of Bangladeshi workers in 2009 is the direct fallout of the economic slowdown caused by the recent global financial crisis. Despite the tremendous growth in overseas employment of Bangladeshi migrant workers, the last few years have also witnessed increased competition from new migrant labor sending countries like Nepal, Cambodia, and Viet Nam (Siddiqui, 2005).

In terms of skill composition of the short-term migrant workers from Bangladesh, professional workers like doctors, engineers, teachers, and nurses constituted less than 5 percent in 2004 and this ratio has drastically dropped to almost 0 in 2008 . Skilled workers such as manufacturing or garment workers, drivers, computer operators, and electricians accounted for about 32 percent, and semi-skilled workers like tailors and masons accounted for another 16 percent of the total migrants in 2008 . Unskilled workers accounted for the rest (about 52 percent). Most of the short-term migrants are male and the female migrant workers accounted for less than 2 percent in 2008. This ratio was about 5 percent during 2005-06. ${ }^{7}$ There are government restrictions on migration of female workers. Further, according to a survey conducted by Sharma and Zaman (2009), the average duration of employment for the migrant workers is 6 years. They also find that migration increases with age and the level of education, and then declines beyond a threshold (44 years of age and 9 years of education). In addition, families with land holdings are more likely to migrate than do landless families. This is not unrealistic as there is high upfront cost associated with migration. ${ }^{8}$

Previous studies indicate that most international migration from Bangladesh originates from the districts of Sylhet, Chittagong, Noakhali, Comilla, and Dhaka (Murshid et al., 2002). ${ }^{9}$ While it has its origin in history, it has some important implications for current emigration. For instance, there are some interesting links between destinations and origins. For example, the Bangladeshi migrants in the Tower Hamlets in the U.K. mostly came from Sylhet. Similarly, migration to Rome mostly 
originates in Faridpur district. This points to the strong network effects among the immigrants. These places also serve as the first stepping stone for international migration and, therefore, receive a lot of internal migrants who hope to eventually go abroad. In recent years, the recruiters of temporary migrant workers, who bear the burden of guaranteeing a smooth supply of adequately skilled and reliable workers, chose to minimize information asymmetries and moral hazard by recruiting within narrow social or community networks where information flows are better and labor contracts are easier to monitor and enforce (Sharma \& Zaman, 2009).

It is important to note that the government plays an important role in the outmigration of Bangladeshi workers. The Emigration Ordinance of 1982 is the key regulatory instrument used by the government with respect to migration. However, several statutory regulatory orders and framed rules introduced subsequently have played complementary or supplementary roles to this instrument. Five government ministries are involved in international labor migration: (i) the Ministry of Expatriates' Welfare and Overseas Employment that was created in 2001; (ii) the Ministry of Home Affairs; (iii) the Ministry of Foreign Affairs; (iv) the Ministry of Finance; and (v) the Ministry of Civil Aviation and Tourism (Siddiqui, 2005). The first of these five ministries is primarily responsible for the migration sector and it pursues the twin goals of creating employment opportunities overseas and addressing problems experienced by expatriates to ensure their well being. Under this ministry, the Bureau of Manpower, Employment and Training (BMET) is the executing agency, responsible for a wide variety of functions ranging from control and regulation of migrant worker recruiting agents to organizing pre-departure briefing sessions for the migrant workers and resolving legal disputes. ${ }^{10}$ The Bangladesh missions abroad also play an important role in labor migration by performing the following tasks: (i) exploration of potential labor market; (ii) attestation of recruitment documents; (iii) consular services to Bangladeshi workers; and (iv) ensuring the welfare of migrant workers.

The Bangladesh Overseas Employment Services Limited (BOESL) is the government agency that is involved in direct recruitment of workers for international migration. During 1976-2003, less than 2 percent of the migrant workers were assisted by the government agencies (BMET and BOESL) and about 41 percent received assistance from private recruitment agencies which are licensed by the government, and organized under the national umbrella organization called Bangladesh Association of International Recruitment Agencies (BAIRA). ${ }^{11}$ However, more than 55 percent of migrant workers were recruited through individual initiatives and social networks. ${ }^{12}$ 
The international migrants from Bangladesh face a number of problems in both home country and host country. For example, the initial cost of international migration could be prohibitively high. There are allegations of exploitation by recruitment agents and foreign employers. There are reports of racial and ethnic discrimination in host countries of Middle East and Southeast Asia. Both home and host countries are lax in formulating appropriate policy to protect the rights of the migrant workers and their families. Most major destination countries have not ratified the 1990 International Convention on the Protection of Rights of All Migrant Workers and Members of their Families. ${ }^{13}$

\section{Remittance Flows into Bangladesh}

\section{Size, Growth, and Origins of Remittances}

According to official statistics published by Bangladesh Bank, a total amount of USD 67.67 billion has been remitted to Bangladesh from across the globe between 1975-76 and 2008-09. However, if we add the amount of remittances transferred through informal channels and therefore not captured in the official data, this number will be much higher. As Figure 3 shows, except for a few years in early 1980s and one year around 2000, the remittance flow has been steadily increasing with an acceleration in the growth rate in recent years. The Iran-Iraq War seems to explain the slowdown in the growth of remittances in the early 1980s. Similarly, the Gulf War of the early 1990s may have been the reason for sluggish growth in remittances during that period. It should be noted that the recent spur in the growth of remittances can partially be ascribed to increased use of formal channels of remitting money from abroad for a variety of reasons. They include increased efficiency and larger network of formal channels that involve both nationalized commercial banks (NCBs) and private commercial banks (PCBs), somewhat stricter enforcement of laws against informal channels like the hundi system (which are supposedly used for transfer of funds among terrorist groups) after the terrorist attack of September 11, 2001 , and various government programs to encourage remittance transfers. ${ }^{14}$

Most remittance flows originate in Middle East. Figure 4 presents total remittance transfers by country of origin between 1998-99 and 2009-10. As the figure shows, Saudi Arabia alone is the source of more than USD 18 billion in remittance transfers to Bangladesh between the fiscal years of 1998-99 and 2009-10. Over the same period, the United States has been the second largest source of remittances with USD 8 billion, followed by the United Arab Emirates with USD 7.1 billion, Kuwait with USD 5.7 billion, and the United Kingdom with 4.8 billion. It is clear 
from the figure that the largest share of the remittances originate in countries that receive most of the short-term migrant workers.

Figure 3

Remittance Flows into Bangladesh: 1976-2009

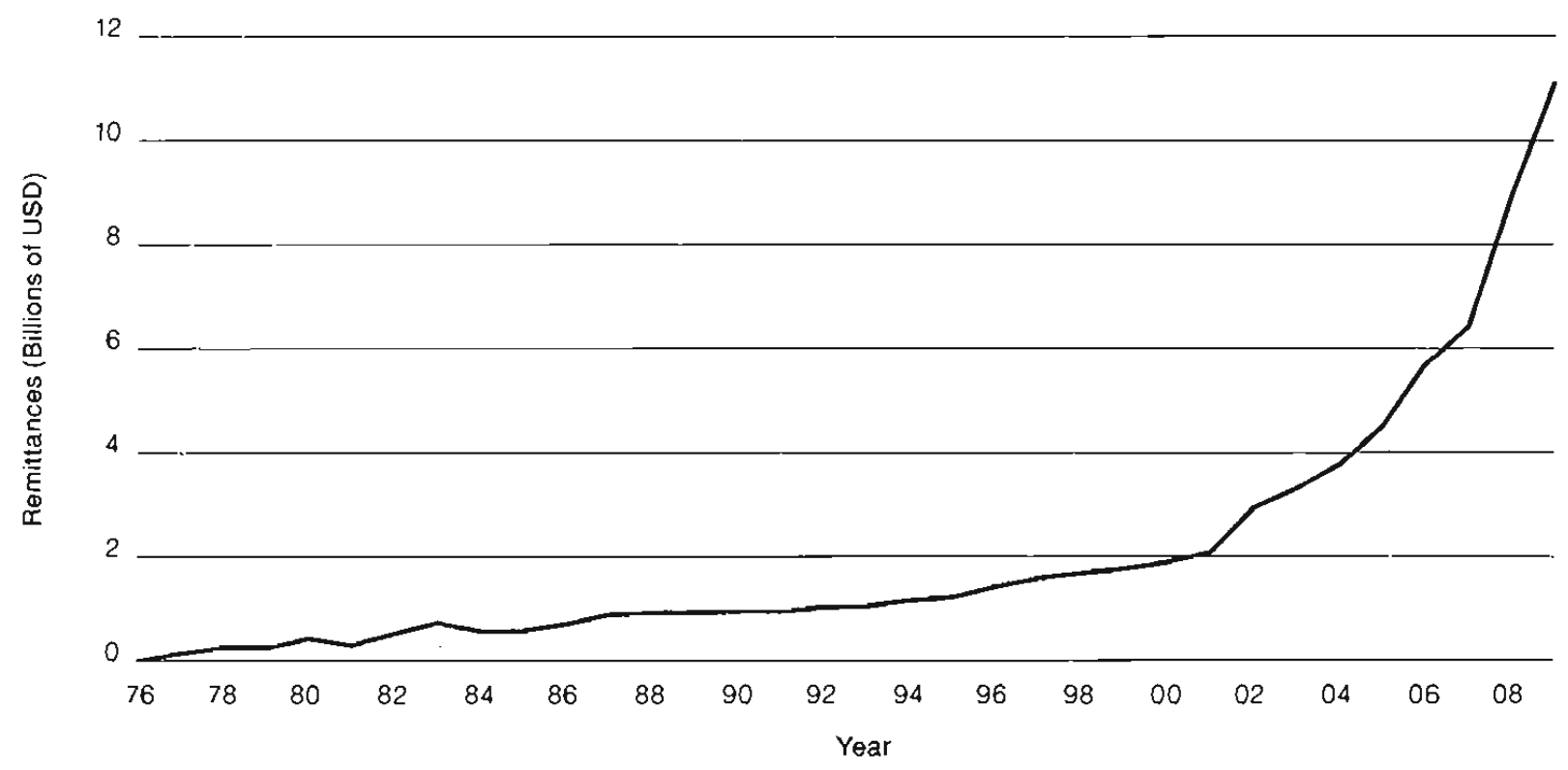

Figure 4

Remittance into Bangladesh by Country of Origin: Total Between 1998-2009

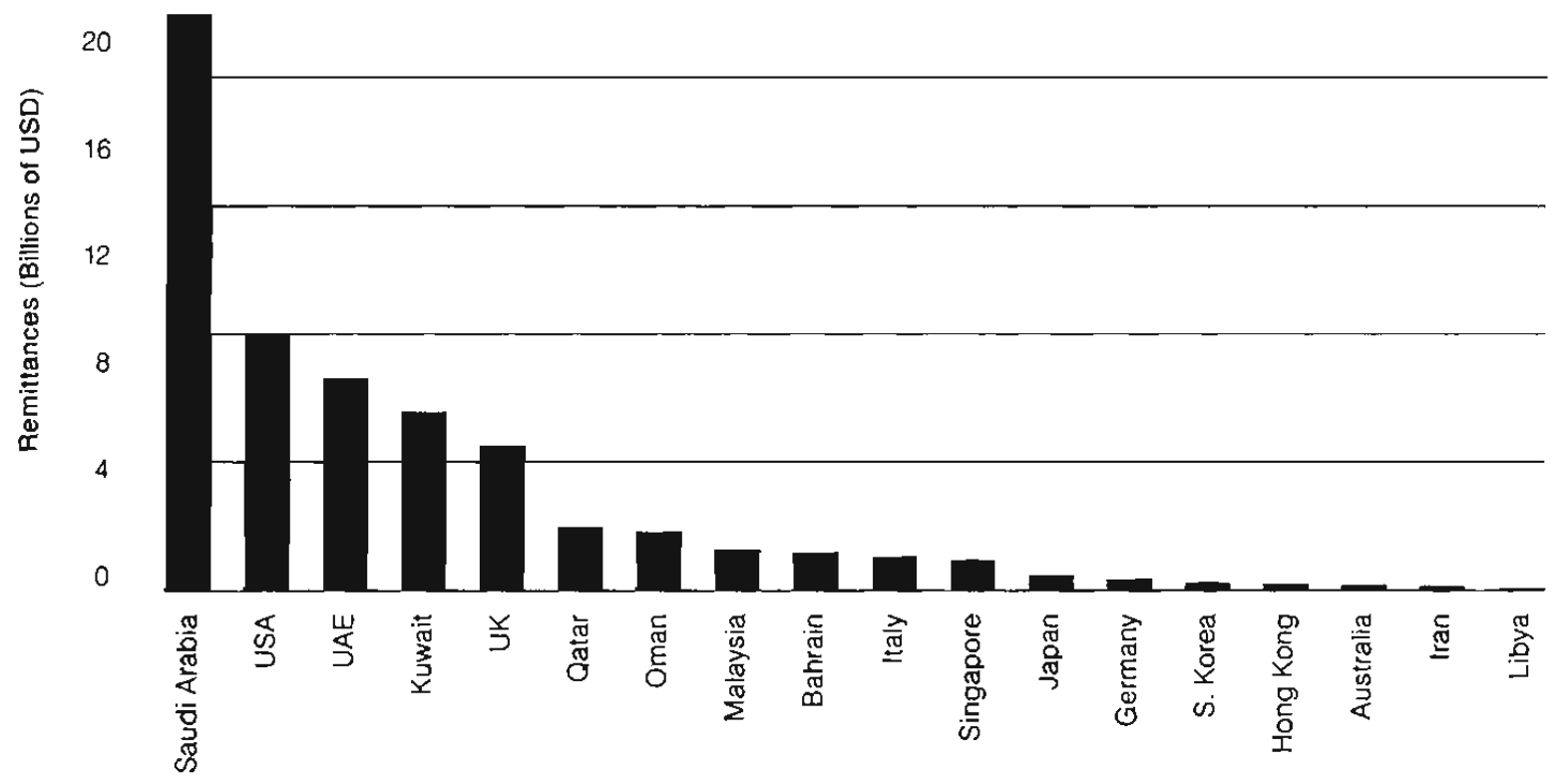


Table 2

Workers' Remittances into Bangladesh by Country of Origin:

1998-99 - 2009-10 (millions of US Dollars)

\begin{tabular}{|c|c|c|c|c|c|c|c|c|c|c|c|c|c|}
\hline Country & $\begin{array}{l}1998- \\
1999 \\
\end{array}$ & $\begin{array}{l}1999- \\
2000\end{array}$ & $\begin{array}{c}2000- \\
2001 \\
\end{array}$ & $\begin{array}{l}2001- \\
2002 \\
\end{array}$ & $\begin{array}{l}2002- \\
2003 \\
\end{array}$ & $\begin{array}{l}2003- \\
2004 \\
\end{array}$ & $\begin{array}{l}2004- \\
2005 \\
\end{array}$ & $\begin{array}{c}2005- \\
2006 \\
\end{array}$ & $\begin{array}{c}2006- \\
2007 \\
\end{array}$ & $\begin{array}{l}2007- \\
2008 \\
\end{array}$ & $\begin{array}{l}2008- \\
2009 \\
\end{array}$ & $\begin{array}{c}2009- \\
2010 \\
\end{array}$ & Total \\
\hline Bahrain & 38.94 & 41.8 & 44.05 & 54.12 & 63.72 & 61.11 & 67.18 & 61.29 & 79.96 & 138.2 & 157.43 & 98.69 & 906.49 \\
\hline Kuwait & 230.22 & 245.01 & 247.39 & 285.75 & 338.59 & 361.24 & 406.8 & 454.38 & 680.7 & 863.73 & 970.75 & 602.67 & 5687.23 \\
\hline Oman & 91.93 & 93.01 & 83.66 & 103.27 & 114.06 & 118.53 & 131.32 & 153 & 196.47 & 220.64 & 290.06 & 218.72 & 1814.67 \\
\hline Qatar & 63.94 & 63.73 & 63.44 & 90.6 & 113.55 & 113.64 & 136.41 & 161.43 & 233.17 & 289.79 & 343.36 & 222.94 & 1896 \\
\hline K.S.A. & 685.49 & 916.01 & 919.61 & 1147.95 & 1254.31 & 1386.03 & 1510.46 & 1562.21 & 1734.7 & 2324.23 & 2859.09 & 1985.13 & 18285.22 \\
\hline U.A.E. & 125.34 & 129.86 & 144.28 & 233.49 & 327.4 & 373.46 & 442.24 & 512.64 & 804.84 & 1135.14 & 1754.92 & 1100.45 & 7084.06 \\
\hline Libya & 0.14 & 0.04 & 0.1 & 0 & 0.16 & 0.13 & 0.27 & 0.16 & 2.61 & 0.36 & 1.25 & 1.01 & 6.23 \\
\hline Iran & 0.19 & 0 & 0 & 0 & 0.22 & 0.38 & 0.52 & 1.68 & 2.36 & 3.24 & 3.28 & 2.74 & 14.61 \\
\hline $\begin{array}{l}\text { Sub total for } \\
\text { Middle East }\end{array}$ & 1236.2 & 1489.5 & 1502.5 & 1915.2 & 2212 & 2414.5 & 2695.2 & 2906.8 & 3734.8 & 4975.3 & 6380.1 & 4232.4 & 35694.51 \\
\hline Australia & 0 & 0 & 0 & 2.28 & 3.38 & 4.79 & 7.15 & 8.89 & $11.34^{\circ}$ & 13.11 & 6.78 & 5.21 & 62.93 \\
\hline Hong Kong & 5.13 & 5.15 & 3.96 & 3.99 & 4.77 & 5.92 & 5.63 & 5.37 & 6.15 & 8.1 & 9.09 & 5.46 & 68.72 \\
\hline Italy & 0 & 0.22 & 0.41 & 0.35 & 19.32 & 27.16 & 41.38 & 78.43 & 149.65 & 214.46 & 186.9 & 128.3 & 846.58 \\
\hline Malaysia & 67.52 & 54.04 & 30.6 & 46.85 & 41.4 & 37.06 & 25.51 & 19.05 & 11.84 & 92.44 & 282.22 & 328.13 & 1036.66 \\
\hline Singapore & 13.07 & 11.63 & 7.84 & 14.26 & 31.06 & 32.37 & 47.69 & 61.32 & 80.24 & 130.11 & 165.13 & 112.59 & 707.31 \\
\hline U.K. & 54.04 & 71.79 & 55.7 & 103.31 & 220.22 & 297.54 & 375.77 & 517.39 & 886.9 & 896.13 & 789.65 & 524.91 & 4793.35 \\
\hline U.S.A. & 239.41 & 241.3 & 225.62 & 356.24 & 458.05 & 467.81 & 557.31 & 701.37 & 930.33 & 1380.08 & 1575.22 & 845.35 & 7978.09 \\
\hline Germany & 5.14 & 4.7 & 3.84 & 6.11 & 9.57 & 12.12 & 10.1 & 10.95 & 14.91 & 26.87 & 19.32 & 11.6 & 135.23 \\
\hline Japan & 39.42 & 34.56 & 10.74 & 14.14 & 18.24 & 18.73 & 15.99 & 8.71 & 10.17 & 16.29 & 14.12 & 9.25 & 210.36 \\
\hline S.Korea & 1.87 & 0.52 & 0.33 & 0.79 & 3.93 & 5.19 & 18.41 & 16.4 & 17.08 & 19.69 & 18.33 & 15.25 & 117.79 \\
\hline Others & 43.95 & 35.95 & 40.53 & 37.63 & 40.02 & 48.76 & 48.15 & 92.56 & 125.05 & 142.17 & 242.36 & 267.19 & 1164.32 \\
\hline $\begin{array}{l}\text { Sub total for } \\
\text { regions other than } \\
\text { Middle East }\end{array}$ & 469.55 & 459.86 & 379.57 & 585.95 & 849.96 & 957.45 & 1153.1 & 1520.4 & 2243.7 & 2939.5 & 3309.1 & 2253.2 & 17121.34 \\
\hline Total & 1705.7 & 1949.3 & 1882.1 & 2501.1 & 3062 & 3372 & 3848.3 & 4427.2 & 5978.5 & 7914.8 & 9689.3 & 6485.6 & 52815.85 \\
\hline
\end{tabular}

Source: Bangladesh Bank 


\section{Determinants of Remittances to Bangladesh}

In general, the literature differentiates between micro and macroeconomic determinants of remittances. ${ }^{15}$ Among the microeconomic determinants, altruism towards the family left behind by the migrants in the home country, investment in home country by "self-interested" migrants, insurance against risks that migrants are exposed to in the host country, and payment back (return) to the family for the investment that it made on the migrant, have been extensively discussed and tested for various remittance receiving communities/countries around the world. At the macro level, movements of foreign exchange rate, differences in interest rates between host and home country, and business cycle fluctuations in host and home country of the migrants have been shown to be important determinants.

There have been only a few studies that explore the determinants of remittance transfers to Bangladesh. These studies seem to focus on macroeconomic determinants. For example, Barua, Mahumber, and Akhtauzzaman (2007) show that income differentials between host and home country and devaluation of home country currency positively and high inflation rate in home country negatively affect workers' remittance decision. Using a simple regression analysis, Hussain and Naeem (2010) find that number of workers finding employment abroad every year, oil price, exchange rate, and GDP growth are the key determinants of changes in the level of remittance inflow into Bangladesh. According to their results, each additional migrant worker increase remittances by USD 816 annually. Furthermore, a one dollar increase in oil price increases annual remittance transfers to Bangladesh (mainly from Middle East) by nearly USD 15 million. They also find that depreciation of exchange rate by one Bangladeshi taka increases annual remittance by USD 18 million and that remittances are higher during periods of low economic growth in Bangladesh. The last result is consistent with the finding of Sayan (2006) who shows that migrants from Bangladesh increase their remittance transfers during times of economic hardship in their home country.

\section{Economic Impacts of Remittances in Bangladesh}

\section{Microeconomic Impacts}

It has been a general conclusion of most micro-level studies that the remittance-receiving households use the largest fraction of remittances for consumption. However, purchase of land, construction and repair of houses, and repayment of loans have been some of the other important uses of remittances. 


\section{Table 3}

\section{Percentage Distribution of Remittances by Expenditure Categories}

\begin{tabular}{lc}
\hline Expenditure Categories & $\begin{array}{c}\text { Range of percentage share } \\
\text { of remittances spent }\end{array}$ \\
\hline Food and clothing & $20-36$ \\
Purchase of land & $3-40$ \\
Home construction and repair & $2-30$ \\
Repayment of loans & $10-19$ \\
Wedding and other social ceremonies & $0-10$ \\
Education & $0-5$ \\
Savings & $3-7$ \\
Funding other peopleis migration & $0-7$ \\
Investment in business & $0-5$ \\
Health care & $0-4$ \\
\hline
\end{tabular}

Source: Compiled from various studies

Various survey-based studies indicate that family transfers account for up to 70 percent of the total household income. Some studies (e.g., Afsar et al., 2002) suggest that over time households with overseas labor migrants become increasingly dependent on remittances. Most surveys also indicate that remittances are mainly used for consumption (Siddiqi \& Abrar, 2001; Afsar, 2003). Depending on how consumption is defined, as much as 80 to 90 percent of remittances are used for this purpose. Table 3 presents the percentage distribution of remittances spent by the most important expenditure categories. Note that it presents the range of percentage shares of remittances spent on these items as reported by various micro-level studies. Whether all items can be included in consumption is disputable. While it is not surprising that between $1 / 5^{\text {th }}$ and $1 / 3^{\text {rd }}$ is spent on basic items like food and clothing, it is interesting to note that up to 40 percent of remittances are spent on purchase of land. Land is the safest way to invest in Bangladesh. As Siddiqqi and Abrar (2001) argue, arable land provides direct economic return through crop production. Furthermore, in a land-shortage economy like Bangladesh, the value of land appreciates very quickly. Repayment of loans also accounts for a large share of the total use of remittances. These findings are further corroborated by Sharma and Zaman (2009). They find that while the remittance-receiving families spend more on consumption of food and non-food items, the same is not true for health and education expenditure. They also note that their spending on home appliances and land are higher than non-migrant 
families'. Finally, remittance-receiving families save more and have more outstanding loans (resulting mainly from high upfront cost of migration). However, it also shows their credit-worthiness.

In an interesting study, Mohapatra, Joseph, and Ratha (2009) find that the remittance-receiving households in Bangladesh had higher per-capita consumption than others after the devastating floods of 1998. Based on household survey data, this study emphasizes the role of remittance transfers as a consumption smoothing mechanism in the face of natural disaster.

There are instances of some non-resident Bangladeshis (NRB) making individual contributions every year to mosques, orphanages, or madrassas. Also, there are Bangladeshi immigrants - mainly in the USA and the UK - who come from the same region/area and organize to pool money and transfer to the respective areas of their origin for charity or community development. The money is given for health care, religious projects, educational projects, construction and repair of roads and culverts, and the provisions of scholarships to students in the villages where the expatriates come from. However, the total transfer is very small and not well known to formal/government institutions in Bangladesh.

\section{Macroeconomic Impacts of Remittances}

To give a perspective on how important remittances could be for economywide impacts, Table 4 presents comparisons of these transfers with GDP, foreign direct investment (FDI), total merchandize export earnings, and official foreign aid in Bangladesh between 2000 and 2008. By 2008, remittances are already more than 11 percent of GDP. The remittances have far exceeded the official foreign aid and FDI into Bangladesh. The flow of remittances as a share of total export earnings has increased over the years and was about 65 percent in 2008. These comparisons signify the importance of remittances for the overall economy in Bangladesh.

As most micro-level studies show, the remittances directly augment household income and increase consumption. Thus, although remittances do not seem to have contributed to the macro economy, the increases in income and consumption at the household level have some significant macroeconomic consequences. For example, in a note prepared for the G8 Outreach Event on Remittances in Berlin, Ratha and Mahapatra (2007) state that remittance may have reduced the share of poor people in the population by 6 percentage points in Bangladesh. In a recent study, Raihan, Khondker, Sugiyarto, and Jha (2009) further show that a 1.7 percentage point reduction in headcount ratio measure of poverty level between 2000-05 can be attributed 
to the growth in remittances. This finding is further corroborated by Vargas-Silva, Jha, and Sugiyarto (2009) who use several different measures of poverty.

Table 4

\section{Comparison of Remittances with Key Macro Variables}

\begin{tabular}{ccccc}
\hline & \multicolumn{4}{c}{ Remittances as a percentage share of } \\
\cline { 2 - 5 } Year & GDP & FDI & $\begin{array}{c}\text { Merchandise } \\
\text { Exports }\end{array}$ & $\begin{array}{c}\text { Foreign } \\
\text { Aid }\end{array}$ \\
\hline 2000 & 4.15 & 337.88 & 34.97 & \\
2001 & 4.41 & 584.21 & 36.11 & 151.2805 \\
2002 & 5.98 & 867.44 & 52.32 & 197.4889 \\
2003 & 6.12 & 907.38 & 51.01 & 200.4814 \\
2004 & 6.30 & 774.39 & 47.00 & 344.8075 \\
2005 & 7.05 & 502.94 & 50.03 & 285.0349 \\
2006 & 8.86 & 691.56 & 47.08 & \\
2007 & 9.60 & 986.19 & 51.61 & 402.6996 \\
2008 & 11.37 & 826.80 & 64.59 & 435.451 \\
\hline
\end{tabular}

Source: Authors' calculations using data obtained from UNCTAD, Bangladesh Bank, and the World Bank.

Furthermore, it is important to recognize that even though remittance receiving households may not directly invest the funds that they receive through transfers from the migrant member, the increase in consumption itself should work its way through multiplier effect on the aggregate demand and, therefore, should contribute positively to growth. Also, it has been noted above that the remittance-receiving households save a part of their remittance transfers. Further, there is some evidence that Bangladeshi immigrants also transfer funds directly to the home country in order to save. Over the years, government and banks have been able to attract savings from individual immigrants by creating a number of bonds and special savings accounts aimed at migrants (de Bruyn \& Kuddus, 2005). However, the amount transferred directly for investment is very low. ${ }^{16}$ But as long as the savings of the remittance-receiving households and the migrant workers enter the formal financial system in Bangladesh, they are used to finance investment and, consequently, they contribute to long-run growth. In addition, increasing use of the financial system to transfer funds itself should channel some of these remittance flows into productive investment. 
Thus, to assess the macroeconomic impact of remittance transfers, we will present (i) an illustration of the multiplier effects of remittances on sectoral level output using the input-output framework; (ii) some tentative results from a vector autoregressive (VAR) macro model.

\section{The multiplier effects of remittances at the sectoral level}

Stahl and Habib (1989) analyze the impact of remittances at the sectoral level by using the input-output framework. They use survey data from a World Bank study on the expenditure patterns of remittance-receiving households in Bangladesh and match them to the 47 sectors comprising the input-output table for Bangladesh. This sectoral distribution of expenditures is imputed to total remittances inflow data for the years between 1976 and 1988 to obtain corresponding sector-wise anticipated expenditures out of remittances. Assuming these expenditures to be autonomous additions to final demand attributable to remittances, they are then multiplied by the output multiplier matrix $[I-A+m]^{-1}$ to obtain total output attributable to remittances. Note that here $A$ is the technical coefficient matrix given by the input-output table, and $m$ is the diagonal matrix with import coefficients as the diagonal elements. The results for the most important sectors are summarized in Table 5.

If the remittances are spent on sectors that have strong forward and backward linkages with many other sectors, the overall impact on output is high. For example, according to our calculations, if a dollar of remittances is spent on forestry, it will lead to an increase of about USD 5 in output. Forest products such as bamboos, woods, canes, are used as intermediate inputs to produce a variety of goods. Thus, an initial expenditure on these products may lead to a much larger increase in overall output. 


\section{Table 5}

\section{Remittance Induced Output in Bangladesh}

\begin{tabular}{lc} 
& $\begin{array}{c}\text { Increase in output when USD 1 of } \\
\text { remittances is spent (in USD) }\end{array}$ \\
\hline Rice & 1.09 \\
Other crop & 1.21 \\
Live stock & 1.34 \\
Fisheries & 1.00 \\
Forestry & 4.91 \\
Leather & 1.18 \\
Wood & 1.52 \\
Miscellaneous industries & 2.67 \\
Urban house & 1.10 \\
Rural house & 1.04 \\
Petroleum & 1.73 \\
Electricity & 1.42 \\
Transport service & 1.74 \\
Banking service & 1.37 \\
Other service & 1.11 \\
\hline
\end{tabular}

Source: Authors' calculations from the results reported in Stahl \& Habib (1989).

\section{Some tentative results on the macroeconomic effects of remittances from a VAR model ${ }^{17}$}

We now examine the effects of remittances at the macro level by using a vector autoregression (VAR) macro model of the following form: ${ }^{18}$

$$
Y_{1}=A_{0}+\sum_{i=1}^{p} A_{i} Y_{t-i}+\varepsilon_{t}
$$

where $Y$ is an $n \times 1$ vector of macro variables, $A_{0}$ is an $n \times 1$ vector of constants, $A_{i}$ is an $n \times p$ matrix of autoregressive coefficients of lagged variables, and is an $n \times 1$ vector of error terms. Although we would like to include a number of important macro variables in this model, limited availability of data for Bangladesh allows us to use the following variables only: Industrial Production, CPI, Export Receipts, Import Payments, MI Money Stock, Remittances, and the Nominal Exchange Rate of US Dollar in terms of Bangladeshi Taka. For each variable, we use monthly data for 
a period between July 1994 and December 2008. The data are seasonally adjusted. We conduct Augmented Dickey Fuller (ADF) Test on each series to determine its stochastic trending properties. Except for $M 1$ and Remittances, all other series are found to be unit root processes. Therefore, we use their stationary forms. That is, we use $\log$ first differences of all series including $M 1$ and Remittances. We estimate equal lag length VAR with lags of up to 6 months. ${ }^{19}$ We then derive the generalized impulse responses of each of the variables to a one standard deviation shock to remittance growth. ${ }^{20}$ Figure 5 presents the generalized impulse responses for 12 months.

As we see from the figure, a one standard deviation shock to the growth of remittances has significant positive impact on the growth of industrial production, export growth, and the change in nominal exchange rate in month 1 . However, the effects quickly dissipate after the second month. ${ }^{21}$ Note that since we include CPI inflation in the model, these results should be interpreted as real effects of a shock to real remittance growth. It is hard to speculate on the actual mechanism through which these macro variables are affected by remittance growth in Bangladesh without exploring more on the structure of the economy. Also, it is imperative to use a more general VAR specification with additional endogenous macro variables. But given the data limitations, it is outside the scope of the current study. Thus, the results presented in Figure 5 should be taken to be indicative of potential effects of remittances on the overall economy and should not be overemphasized as evidence of precise effects on the respective macro variables. 


\section{Figure 5}

\section{Generalized Impulse responses from a}

Vector Autoregression Macroeconomic Model

Generalized Impulse Responses to a One S.D. Shock to Remittances
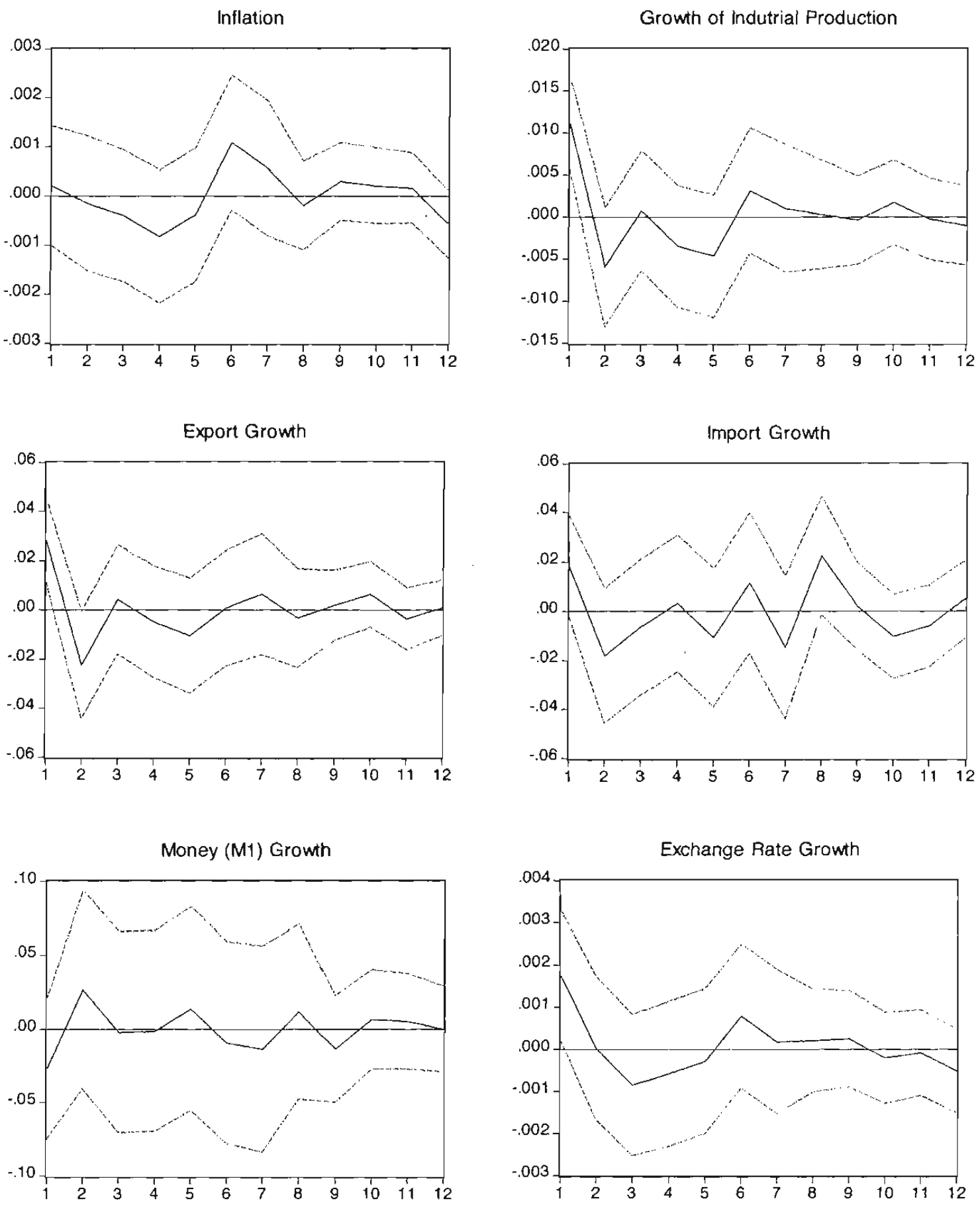


\section{Concluding Remarks}

The officially recorded number of migrant workers from Bangladesh to over 140 countries during more than three decades since the mid-1970s stands at over 6.7 million. Most of these workers are temporary migrants working mainly in Middle East and Southeast Asia. This mass movement of temporary migrant workers has, to some extent, eased unemployment pressures on over-burdened labor market of highly populated Bangladesh. More importantly, the remittance transfers from these migrant workers have reached a phenomenal level of about 12 percent of GDP in Bangladesh. The existing studies have shown that most of these remittance transfers augment household income and are used for consumption. However, there has been evidence to show that these remittances have helped reduce poverty in Bangladesh. The analysis presented in this paper further indicates that these transfers may have significant effects on other macroeconomic variables as well.

As pointed out in the paper, international migration of temporary workers from Bangladesh has been a key strategy of the government's employment policy. A country with half of the U.S. population and less than 1 percent of the U.S. GDP, Bangladesh does not have too many options. Emigration of a large segment of the population to high or middle income countries has been suggested as a way of eradicating abject poverty (Moses, 2009). The remittances received from the migrant workers have been significantly large in recent years. It is important to understand how these transfers impact the economy at the macro level so that appropriate policies can be formulated to ensure their optimal utilization. Furthermore, there is hardly any study that examines the overall impact of international migration of workers from Bangladesh. For example, what is its impact on domestic labor markets in terms of employment and wages? How does it affect productivity and growth? Our future research intends to examine in details the macroeconomic impacts of labor migration and remittances in Bangladesh.

\section{$\overline{\text { Notes }}$}

1. This number almost exclusively includes temporary workers who have officially migrated for employment overseas, and does not include most Bangladeshis who have permanently emigrated to Europe and North America and/or those who illegally migrated to other countries, mainly to India. If those groups are included, the number of Bangladeshi migrants will be several times larger.

2. According to the data obtained from the Bureau of Manpower, Employment and Training (BMET), the total remittances received in 2009 amount to USD 10.72 bil- 
lion while, according to Bangladesh Bank, the total remittance transfers amount to USD 9.69 billion during the fiscal year 2008-09 and USD 6.49 billion through the month of January during the fiscal year 2009-10.

3. Bahar, Sarker, and Hossain (2006) cite an IMF report to claim that over 59 percent of total remittance transfers between 1981 and 2000 came through informal channels. In contrast, World Bank (2006) reports this share to be a 54 percent.

4. As quoted by de Bruyn and Kuddus (2005, p.42).

5. In a recent paper, Vargas-Silva, Jha, and Sugiyarto (2009) includes Bangladesh in a panel study of 26 countries from Asia to investigate the macroeconomic effects of remittances on economic growth and poverty reduction.

6. For a survey of the literature, see Ruiz and Vargas-Silva (2009).

7. See Siddiqui (2009).

8. As de Bruyn and Kuddus (2005) note, the initial costs that include airfare, passport, visa, insurance, medical checkup, clothes, payment to recruitment agencies etc. may add up to USD 2,000 or more.

9. Siddiqui (2009) lists Brahmanbaria, Chittagong, Comilla, Dhaka, and Tangail as the highest migration prone districts with $5.67,9.06,11.48,6.48$, and 6.13 percent of the migrant workers respectively coming from these districts.

10. The government created BMET in 1976, much before the creation of the Ministry of Expatriatesí Welfare and Overseas Employment, to ensure maximum benefit from labor migration to the national economy. Since the enactment of the Emigration Ordinance of 1982, it has been responsible for implementing the Ordinance.

11. There are more than 700 officially licensed private recruitment agencies.

12. See Table 3 in Siddiqui (2005).

13. See Bryun and Kuddus (2005) and Siddiqui (2005).

14. For a discussion on the hundi system and other informal channels through which remittances are transferred from East and Southeast Asia, see Rahman and Yeoh (2006) 15. For a detailed discussion, see Ruiz and Vargas-Silva (2009)

16. The previous studies ascribe it to a host of reasons including lack of promotional support in terms of information, advisory, training and other services, lack of ideas about investment opportunities, lack of expertise in the remittance receiving house- 
holds for running businesses, and high opportunity costs in terms of investment environment abroad.

17. We call these results "tentative" mainly for two reasons. First, the limited availability of data restricts the number of variables and the length of the sample period we could use in our VAR estimation. Second, the quality of the data used are of suspect. Sometimes data collected from two different agencies do not quite match. There are data discontinuities. Data on some of the series are not documented well.

18. VAR macro models are very flexible (and, therefore, somewhat popular) in that they can be used to examine relationships between variables without subscribing to any particular theory about such relationships. However, the specification of the model as regards to what endogenous variables and how many lags of those variables are to be included is a contentious issue that the researchers must pay attention to. For a discussion on VAR models, see Enders (2004).

19. Because of the short sample period, we have used 6 lags. However, with 12 lags, the results do not change qualitatively.

20. One advantage of generalized impulse responses is that, unlike impulse responses derived from Cholesky decomposition, they do not depend on the ordering of the endogenous variables.

21. These transitory effects are reminiscent of an aggregate demand shock. However, in the light of the existing literature, it is not clear why remittances would have a positive impact on export growth. The literature (e.g., Amuedo-Dorantes \& Pozo, 2004) argues that large remittances reduce export competitiveness through exchange rate appreciation.

\section{References}

Afsar, R., Yunus, M., \& Islam, A.B.M.S. (2002). Are migrants after the "Golden Deer"? A study on cost-benefit analysis of overseas migration by Bangladeshi labour. International Organization for Migration (IOM), Regional Office for South Asia, Dhaka.

Afsar, R. (2003, June 22-24). Internal migration and the development Nexus: The case of Bangladesh. Paper presented at the Conference on Migration, Development, and Pro-poor Policy Choices in Asia, Dhaka. Retrieved from: http://www. livelihoods.org/hot_topics/docs/dhaka_cp_6.pdf.

Al Hasan, R. (2006). Harnessing remittances for economic development of Bangladesh. INAFI Bangladesh Working Paper Series, No. 1 
Amuedo-Dorantes, C., \& Pozo, S. (2004.) Workers remittances and the real exchange rate: A paradox of gifts. World Development, 32(8), 1407-17.

Bahar, H., Sarker, A. A., \& Hossain, B. (2006). The flow of workers' remittances in Bangladesh: Performance, challenges and policy options. Draft Working Paper, Bangladesh Bank, Dhaka.

Barua, S., Majumder, Md. A., \& Akhtauzzaman, M. (2007). Determinants of workers'remittances in Bangladesh: An empirical study. Working Paper Series: WP 0713, Policy Analysis Unit, Bangladesh Bank.

De Bruyn, T., \& Kuddus, U. (2005). Dynamics of remittance utilization in Bangladesh. IOM Migration Research Series, No. 18. Geneva, Switzerland: International Organization for Migration.

Enders, W. (2004). Applied econometric time series (2nd ed.). New York: John Wiley \& Sons, Inc.

Hussain, Z., \& Naeem, F. (2010). Remittances in Bangladesh: Determinants and 2010 outlook. End Poverty in South Asia Blog. The World Bank. Retrieved from: http://blogs.worldbank.org/endpovertyinsouthasis.

Joarder, M. A. M., \& Hasanuzzaman, S. (2008). Migration decision from Bangladesh: Permanent versus temporary. Asia Europe Journal, (6), 531-545.

Mohapatra, S., Joseph, G., \& Ratha, D. (2009). Remittances and natural disasters: Ex-post response and contribution to ex-ante preparedness. Policy Research Working Paper 4972. The World Bank.

Moses, J. W. (2009). Leaving poverty behind: A radical proposal for developing Bangladesh through emigration. Development Policy Review, 27(4), 457 -479.

Murshid, K.A.S., lqbal, K., \& Ahmed, M. (2002). A study on remittance inflows and utilization. International Organization for Migration (IOM), Regional Office for South Asia, Dhaka.

Rahman, Md. M., \& Yeoh, B. S.A. (2006). The social organization of remittances: Channeling remittances from East and Southeast Asia to Bangladesh. Asian Meta Centre Research Paper Series, No. 20.

Raihan, S., Khondker, B. H., Sugiyarto, G., \& Jha, S. (2009). Remittances and household welfare: A case study of Bangladesh. ADB Economics Working Paper Series, No. 189. Asian Development Bank.

Ratha, D., \& Mohapatra, S. (2007, November 28-30). Increasing the macroeconomic impact of remittances on development. Note prepared for the G8 Outreach Event on Remittances, Berlin. Ruiz, I., \& Vargas-Silva, C. (2009). To send, or not to send: That is the question. A review of the literature on workers' remittances. Journal of Business Strategies, 26(1), 73-98. 
Sayan, S. (2006). Business cycles and workers'remittances: How do migrant workers respond to cyclical movements of GDP at home? IMF Working Paper: WP/06/52.

Sharma, M., \& Zaman, H. Who migrates overseas and is it worth their while? An assessment of household survey data from Bangladesh. Policy Research Working Paper 5018. The World Bank.

Siddiqui, T., \& Abrar, C. R. (2001). Migrant worker remittances and micro-finance in Bangladesh. Social Finance Programme Working Paper No. 38. International Labour Office.

Siddiqui, T. (2004). Efficiency of migrant workers' remittance: The Bangladesh case. Manila: Asian Development Bank.

Siddiqui, T. (2005). International labour migration from Bangladesh: A decent work perspective. Working Paper No. 66. Policy Integration Department, National Policy Group. International Labour Office, Geneva.

Siddiqui, T. (2009, April 23). Migrant workers' remittances to Bangladesh; Implications of global recession. Lecture delivered at Bangladesh Institute of International and Strategic Studies (BIISS), Dhaka. (The slides are available at http:// www.biiss.org/tasnem.pdf.)

Stahl, C. W., \& Habib, A. (1989). The Impact of overseas workers' remittances on indigenous industries: Evidence from Bangladesh. The Developing Areas, 27(3): 269-285.

Vargas-Silva, C., Jha, S., \& Sugiyarto, G. (2009). Remittances in Asia: Implications for the fight against poverty and the pursuit of economic growth. ADB Economics Working Paper Series, No. 182. Asian Development Bank.

World Bank. (2006). Global Economic Prospects, Washington: World Bank.

\section{Biographical Sketch of Authors}

Khawaja A. Mamun is an Assistant Professor of Economics at John F. Welch College of Business, Sacred Heart University, Fairfield (CT). He has several publications in peer-reviewed journals including Applied Economics Letters, Journal of International Trade \& Economic Development, Journal of Urban Economics, and Public Finance Review. Dr. Mamun is also the moderator of Bangladesh Young Economists and the treasurer of the Association for Economic and Development Studies on Bangladesh (AEDSB). He received his Ph.D. in Economics from Southern Methodist University, Dallas (TX).

Hiranya K. Nath is an Associate Professor of Economics at Sam Houston State University. He has published on inflation and relative price behavior, the 
growth of transition economies of Central and Eastern Europe, the growth of Bangladesh, and information economy in refereed journals including Applied Economics, Applied Economics Letters, Applied Financial Economics Letters, California Management Review, Comparative Economic Studies, Economics Letters, Journal of International Trade \& Economic Development, Journal of Macroeconomics, Journal of Money, Credit and Banking, and Review of Development Economics. He earned his Ph.D. in Economics from Southern Methodist University, Dallas (TX). 